\title{
9 Sweden
}

\section{Electricity certificate champion}

\author{
Elin Lerum Boasson, Hugo Faber and \\ Karin Bäckstrand
}

\section{Introduction}

In the late 1990s, electricity certificate schemes were strongly favoured by the European Commission (the Commission) as well as the electricity industry, but 20 years later Sweden is the only EU/EEA country with certificates as its main renewables support scheme. In addition, the Swedish government offers tax exemptions and investment support for solar photovoltaics (PVs). Sweden seems to have been unaffected by the two dominant policy approaches to promoting renewable energy in EU countries: the diffusion of feed-in schemes in the period 2000-2010, and the shift to feed-in premium combined with auctioning that has occurred since 2010 (Boasson 2021b, this book).

The research question that guides this chapter is: Why has Sweden electricity certificates combined with technology-specific solar investment support, apparently without being influenced by European policy trends in renewable energy? The certificate scheme is technology-neutral. The amount of renewables in the scheme is subject to political decisions, but the supply and demand of electricity certificates determine the certificate price. The Swedish scheme was introduced as early as in 2003, and in 2016 the certificate scheme was prolonged until 2030, setting 2045 as an end-date of support to projects included in the scheme. This chapter traces the historical development of Swedish renewables policy from the 1970s and onwards, and identifies factors that can explain the Swedish exceptionalism in renewable energy policy.

Sweden harnessed much of its potential for large hydropower in the post-Second World War era. In the late 1970s, nuclear energy became a highly contested political issue, and an advisory referendum in 1980 determined that all nuclear should be phased out by 2010. The public contestation of nuclear power later paved the way for political willingness to promote alternative and new renewable energy sources, reinforced by the advent of climate-change threat in the early 1990s. For over 40 years, nuclear energy has been a heated political issue in Sweden. Renewables have seldom been at the centre of political conflicts.

A main assumption of this book is that the influence of what has been termed the 'European environment' will be strongest at times when the EU wields considerable formal authority and where one policy recipe is dominant. However, 
the Swedish case study runs counter to this expectation: the EU emerges as most influential when it has had less formal authority and when many competing renewables support-scheme designs were in circulation in Europe.

In order to explain why the EU has played this role, we explore the relationship between Sweden and the European environment, examining the politics of renewables in Sweden, as well as the special character of the Swedish organizational field of stationary energy (Boasson 2021a, this book). Has Sweden opted for a largely technology-neutral support mix because this was embraced and promoted by a segmented organizational field of stationary energy? Or is the explanation that a political majority has fought for this through political competition? As we will argue, politics play a crucial role, not least due to the close relationship between renewables and the contested issue of nuclear power.

This chapter presents a case that has received limited attention from scholars of Swedish energy and climate policy (for a notable exception, see Åstrand 2005). To our knowledge, no other study has sought to explain the historical development of Sweden's renewables support schemes, and no other study has investigated the relative importance of EU steering, national political steering and the influence of corporate actors and civil servants. We also take into account the influence of the EU's renewables policy as well as EU's state-aid rules. The Swedish case study is especially pertinent as it provides insights into a case where Europeanization that occurred at one point in time froze, and remained in place many decades after the EU had shifted its policy to promote radically different national practices.

\section{Technology-neutral renewables support mix}

Sweden has a mostly technology-neutral renewables support mix, with an electricity certificate scheme for large-scale renewables and an investment support scheme for small-scale renewables. The certificate scheme involves a governmentinduced market for renewable energy securities (SOU 2017). Governmental regulations determine the operation of the market, the key factor being the size of the quota that renewable energy producers are obliged to produce or purchase. The quota level is based on a domestic renewable energy target expressed in TWh. With higher targets, the quotas increase, thereby increasing the demand for certificates. This leads to higher prices, and thus to higher support levels for renewable energy. While the level of support is determined by supply and demand on the certificate market, demand itself is highly dependent on the quota obligation. What the purchaser of a certificate buys is not the actual energy, but a certificate confirming its economic contribution to the operation of green electricity.

One certificate for every MWh produced is allocated to producers of renewable electricity. Distributors are required to hand over a certain number of certificates to the government based on a percentage quota of their energy sales or consumption. Energy-intensive industry is exempted from the quota obligation. If they do not produce renewable energy themselves, they must buy certificates from renewable energy producers, thereby creating a market where producers of renewable 
energy can obtain additional funding. In the end, the additional expense of obtaining certificates is added to the electricity price (Swedish Government 2003).

Wind, solar and tidal power, geothermal energy, new hydropower, existing small-scale hydropower, biofuels in Combined Heat and Power (CHP) and peat in CHP can be included in the scheme (Bergek and Jacobsson 2010: 1258). All producers receive a bonus through the certificate scheme, corresponding to the value of certificates at that point in time. Thus, all are also exposed to the market price of electricity. Further, as all energy sources receive the same amount of certificates per MWh, this support is technology-neutral. It aims at expanding the most competitive renewable energy sources and ensuring minimal societal costs by letting the market select the most profitable technologies (ibid.: 1257ff). The scheme has since been prolonged and expanded, but the design has not changed significantly after it was adopted in 2003. The price of the certificates has varied: in late 2016, prices were at an all-time low, around $€ 7$ per certificate (Ekonomifakta 2016).

Sweden adopted an investment support scheme for solar PV on public buildings in 2005. This support covers up-front investment cost, but not operational costs. In 2009, also private individuals and corporations became eligible for investment support for grid-connected solar power (Swedish Government 2009a). Initially, the programme covered $60 \%$ to $80 \%$ of installation costs. It has since been lowered gradually, and since the beginning of 2015 companies can get $30 \%$ and private individuals $20 \%$ of their installation costs covered (Energy Agency 2015: 8). Between July 2009 and September 2016, some $€ 51$ billion were distributed through the scheme; an addition $€ 19$ billion have been granted (Energy Agency 2016). The programme has a fixed budget, providing support on a first come, first served basis. Each year, applications have exceeded annual budgets, leading to lengthy waiting times. The Social Democratic-Green Party government coalition increased the budget of the system for 2016-2019, but waiting times have remained significant (Swedish Energy Agency 2015: 5). Those who feed electricity back to the grid receive the current market price.

In addition, small-scale renewable energy producers can receive a tax reduction of $€ 0.06$ for every $\mathrm{kWh}$ they transfer to the grid, up to $£ 2000$ per year (Swedish Government 2014). Solar power is also included in the certificate scheme, and private persons who hire assistance to install solar cells in their own homes can also get a tax reduction based on the costs of this labour, in line with the general tax reduction for hiring workers to do home renovations in Sweden.

\section{Renewables in the shadow of the nuclear controversy}

\section{Prior to 1999: politicization of nuclear and energy policy in general}

Major political controversy surrounded nuclear energy in the 1970s and 1980s. The rapid expansion of nuclear power in these years spurred political conflicts that were to have repercussions for many decades (Energy Agency 2003: 8).

Sweden had developed a significant portfolio of large hydropower during the 1950s and 1960s (SOU 2017: 96). This led to some minor protests, but energy was 
not a salient political issue in the early 1970s (Kaijser 1992). Rather, experts researchers, civil service officials, industry representatives - enjoyed considerable leeway in determining policies. Increased electricity consumption was largely regarded as a prerequisite for economic growth, industrial competitiveness, increased welfare and high employment in Sweden (Nilsson 2005: 212; Sarasini 2009: 639). At this stage, state-owned Vattenfall - the national transmission system operator and regulator as well as the country's largest electricity producer (Högelius and Kaijser 2010) - saw nuclear electricity generation as the technology of the future (Kaijser 1992: 449).

Sweden's first large-scale nuclear reactor began operation in 1972, with seven more reactors in the pipeline (Kaijser 1992: 447). Then, the international wave of nuclear protest reached Sweden. Eventually, the Centre (formerly Agrarian) Party, the Communist Party and parts of the ruling Social Democratic Party became alerted to the environmental risks related to nuclear energy. The oil crises of the 1970s spurred the politicization of energy policy and the contestation of nuclear energy, in turn paving the way for greater political attention to renewables (Söderholm et al. 2007: 368).

A windpower research programme, initiated in 1975, resulted in a few demonstration wind farms (Engström 2015: 32, 39-40, 203). In addition, direct government support was introduced for bioenergy (Andersson 2013: 20). However, these were marginal developments compared to the rapid expansion in nuclear power. In the 1976 elections, nuclear energy became the main issue. The pro-nuclear Social Democrats lost power, for the first time in 44 years, to a coalition of the Centre Party, the Liberal Party and the (conservative) Moderate Party (Nohrstedt 2005; Vedung and Brandel 2001: 220).

The Centre Party suffered a series of defeats to the pro-nuclear parties in the government, as the construction of new reactors was eventually permitted. So severe were the internal conflicts that the coalition resigned after only two years in power (Nohrstedt 2005; Vedung and Brandel 2001). The conflicts over nuclear expansion made it very hard to create stable governments (Nohrstedt 2005; Nordhaus 1997). The nuclear issue divided the Social Democrats internally, but it also made it difficult for the liberal-conservative parties to form an alternative coalition government. Five major reactors were already under construction in Sweden, but the political conflict regarding nuclear expansion continued. Thus the government decided to hold an advisory referendum in 1980.

All three alternatives offered in the referendum implied an expansion of renewables but were silent on how to achieve this. One alternative called for immediate decommissioning of nuclear plants, but this gained only $39 \%$ of the vote. A second alternative did not imply decommission but added that the state and municipalities should own all future energy facilities also gained 39\% of the vote. Even though no alternative gained more than $50 \%$ of the vote, the outcome enabled the minority government to gain stable parliamentary support in the Swedish Parliament (Riksdagen) (Nordhaus 1997: 33-44). The referendum outcome was followed by a parliamentary decision to: (1) phase out nuclear power by 2010, (2) reduce Sweden's dependence on oil and (3) facilitate the transition to 
'an energy system based as far as possible on lasting, preferably renewable and domestic energy sources with least possible environmental impact' (Kaijser 1992: 445; Wang 2006). However, given the pace of nuclear expansion, the support for renewables was primarily symbolic (Nohrstedt 2005: 1048). When the last reactor was finalized in 1985, Sweden had a sizable electricity surplus (SOU 2017: 99).

In the period leading up to the 1980 referendum, the Swedish electricity industry was unified and dominated by Vattenfall, the national transmission system operator and regulator as well as the largest electricity producer (Högelius and Kaijser 2010). Vattenfall collaborated extensively with the 11 other large energy corporations, and this 'power club' controlled $90 \%$ of Swedish electricity production (see Högelius and Kaijser 2010: 2246). Many smaller municipal energy companies produced some $10 \%$ of the electricity as well as transmitted electricity from the large producers. Inga Carlman (1990) has shown that the utilities saw windpower in particular as a threat to nuclear. Sweden had a significant energyintensive industry, dominated by pulp and paper production. These consumers had rather strong ties to electricity producers and generally supported nuclear expansion (see Högelius and Kaijser 2010: 2246).

Due to the long-term target of phasing out nuclear, renewables gained traction and greater political attention. In 1985, the Social Democratic government initiated more research and development on windpower alternatives ( $̊$ strand and Neij 2003: 22). A few windpower projects were initiated, but the turbines were imported, and no domestic windpower industry emerged (Engström 2015: 53). Moreover, the Chernobyl disaster in 1986 reinforced Sweden's political decision to phase out nuclear as well as to reduce support for its nuclear research and development programme (Högelius and Kaijser 2010: 2247; Kaijser 1992: 457).

At the end of the 1980s, energy policy was still among the most politicized issues in Sweden, but the country lacked both a support scheme for operation of renewable energy and a domestic renewable energy industry. The nuclear controversy had given the politicians the upper hand in energy policy, at the expense of the electricity corporations, which lost authority and control over the issue-area. Swedish policies were clearly influenced by global anti-nuclear protests and rising climate ambitions. In the 1990s, economic liberalization and climate change had climbed the political agenda, in addition to the recurrent debate on nuclear power (Högelius and Kaijser 2010; Nilsson 2005; Sarasini 2009). Moreover, Sweden was headed for a serious financial crisis with wide repercussions for politics, economy and society.

In 1991, the Social Democrats, the Centre Party and the Liberal People's Party agreed to introduce an investment support scheme for wind- and biopower (Åstrand and Neij 2003: 22). The scheme was technology-specific; funds were to be allocated continuously over the annual state budgets (Wang 2006: 1213), frequently leaving no support at the end of the budget cycle.

Simultaneously, economists forcefully argued the way the government regulated and steered energy production and distribution came with significant societal costs, as seen in over-investment in nuclear energy (Högelius and Kaijser 2010: 2248-2249). The government proposed a reorganization of the electricity 
regulation, in order to ensure that profit maximization became the driving force in the energy market, rather than long-term state planning (Högelius and Kaijser 2010: 2248). The Ministry of Finance was supportive, but Vattenfall and the private electricity utilities were initially reluctant. However, this changed rather swiftly as the ensuring liberalization spurred significant merger and acquisition activities (Högelius and Kaijser 2010: 2249-2250). In 1992, Vattenfall was privatized, and transmission grid responsibilities were transferred to the new Swedish transmission grid operator - Svenska Kraftnät (ibid.: 2250). Vattenfall lost no time in developing an international strategy, aiming to become a leading European energy company. Initially, it branded itself as a non-fossil fuel corporation, active primarily in the Nordic countries and the Baltics (Darmani et al. 2016: 12).

Sweden's energy liberalization created significant political turmoil, not least due to internal conflicts among the Social Democrats (Högelius and Kaijser 2010: 2252). However, the Swedish Parliament accepted a liberalization reform in 1995, and the Nordic electricity exchange opened in 1996. This immediately led to market concentration, with three major producers - Vattenfall, Fortum, and Sydkaft/E.ON - controlling 90\% of power generation (ibid.: 2253). Even though Vattenfall Europeanized its activities, our interviewees agree that it did not take an active role in bringing impulses from the EU to Sweden.

Nuclear power remained central for Swedish energy policy in general (Högelius and Kaijser 2010). A windpower production subsidy was introduced in 1994, after a parliamentary initiative from the Centre Party. The size of the subsidy corresponded to the electricity tax paid by consumers (Wang 2006: 1214; Åstrand and Neij 2006: 280). Further, societal cost-efficiency was to serve as a guiding principle for energy-market regulation as well as climate-change mitigation (Nilsson 2005: 215).

Climate change gained increased salience with the new Prime Minister Göran Persson of the Social Democrats and his vision of the 'Green People's Home'. In 1997, the Social Democrats, the Centre Party and the Left Party jointly endorsed an 'ecologic energy transition' agreement (Nilsson 2005: 216). This entailed establishing an Energy Agency with responsibility for renewables and energy efficiency, instructing Vattenfall to become an 'instrument for ecologic transition, and the decommissioning of two nuclear reactors at Barsebäck in southern Sweden (Swedish Government 1997). The need to compensate for this closure spurred further support for renewable energy (Wang 2006: 1212; Åstrand and Neij 2006: 279). Investment subsidies for wind- and biopower were therefore extended until 2002, small-scale hydro was included, and additional funds were secured for operational support to windpower (Swedish Government 2000: 20).

However, as the liberalization of the energy market led to decreasing electricity prices, the new support schemes spurred rather few investments in renewables (Energy Market Inspectorate 2005). It was primarily bioenergy projects related to existing industry activities that profited, a development that transformed many waste and pulp-and-paper actors, previously energy consumers only, into energy producers as well (Jacobsson 2008: 1492). The bioenergy expansion was especially significant as regards district heating (Andersson 2013: 11). However, new 
domestic industries related to new renewable electricity sources, like wind or hydro, did not emerge (Andersson 2013). To the extent that such new renewables were developed, this was undertaken by the traditional electricity actors, first and foremost Vattenfall (Andersson 2013: 14; Wang 2006: 1215).

According to several interviewees, the renewables schemes were widely considered expensive and ineffective. The dependence on yearly allocations over the state budget and lack of flexibility to adjust support levels to the volume of applications created an unreliable stop-and-go system (Åstrand and Neij 2006: 277, 292). Moreover, Sweden became a full member of the EU in 1995 - and the Commission rather quickly signalled that the 'environmental bonus' to windpower was in conflict with EU state-aid rules (Åstrand 2005: 114).

In December 1999, a government task force was set up to develop a new comprehensive and long-term renewable energy support scheme that could replace previous measures. Civil servants dominated the group, but they had regular meetings with energy corporations as well as the political parties (Swedish Government 2000: 20,1). The Commission and Eurelectric (the European confederation of the electricity industry) promoted certificates as the best support measures (Boasson 2021b). The Netherlands had implemented a voluntary certificate scheme and the Danish government had initiated a shift to certificates, but no EU countries had implemented a full-scale certificate scheme. The Swedish government task force visited the two countries in its search for new and better renewables support schemes.

Our interviewees indicate that Swedish civil servants engaged in the thenongoing EU discussions about liberalization of energy markets and development of a pan-European certificate scheme. In the late 1990s, the financial crisis had led the Swedish government to instruct all ministries to set about developing innovative approaches to cut state spending ( $₫$ strand 2005: 112). The first EU Renewables Directive was in the making, and the negotiations 'strengthened the belief among the Swedish civil servants, invoked by the state-aid rules, that the future of other instruments than a certificate trading system was limited' (ibid.: 117). This view was supported by our interviewees. One interviewee (9) explained: 'Every ministry worked like crazy to come up with proposals for how to cut costs from the state budget. When we had discussions with the EU, with [name of EU official] and other enthusiastic people, then we at the energy unit thought, "oh my God, well, then, we can simply apply that [the certificate] idea"'. Several interviewees state that the Commission's initial response to the PreussenElektra court case led Swedish government representatives to assume that only certificate schemes would be endorsed in the future (see also Åstrand 2005: 115). However, no interviewees can recall that Swedish electricity utilities actively called for the introduction of a certificate scheme. Rather, these appeared to focus on other policy issues, such as nuclear energy, decommissioning, market streamlining, and Europeanization.

We have seen that the idea of certificates gained hold in Sweden as early as the late 1990s. It had come from the EU but was compatible with the dominant market modes in the Swedish organizational field since the energy market liberalization. 
The certificate idea created an opportunity to support renewables without using state resources. Three large corporations dominated Swedish electricity production, but they had little influence on renewables policy. Hence, civil service officials enjoyed considerable leeway regarding renewable energy support policies.

\section{0-2004: EU influence and the adoption of a certificate scheme}

At the beginning of the new millennium, political divisions on energy were no longer an impediment to stable Swedish governments. However, nuclear phaseout was still politicized, and the electricity industry had started to adjust its corporate strategy to the liberalized market. There was political consensus on the need to expand domestic renewables, and the Swedish government was highly aware of the ongoing negotiations of the first EU renewables directive and the PreussenElektra court case (Boasson 2021b).

In March 2000, the government task force issued an official report recommending the creation of a certificate scheme (Swedish Government 2000: 20). Anne Bergek and Staffan Jacobsson (2010) as well as Kerstin Åstrand (2005) conclude that the EU had major influence on the work of this Commission. Also, our interviews indicate that Commission officials were directly involved in the drafting of this report.

The government appointed an expert task force to develop a detailed proposal for a certificate scheme design (SOU 2001: 77). According to one interviewee (3), this task force paid special attention to the PreussenElektra court case, assuming the arguments of the Commission would be upheld by the European Court of Justice. The aim was to design a scheme that was as market-streamlined as possible and that did not involve direct use of state aid. The group discussed a technologyspecific design element whereby the most costly energy sources would receive more certificates, but this was rejected on the grounds that it would be difficult to ensure that the volume target was reached. The group then focused on developing a scheme that could be adopted by other countries, enabling the development of an international certificate market (SOU 2001: 77). One interviewee (4) explained: 'This was a couple of years after the deregulation of the electricity market so there was very much of a market focus really, and it was natural to also have a market-based instrument'.

The programmes of the Swedish political parties rarely refer to specific requirements concerning renewables support schemes (Centerpartiet 2001; Folkpartiet Liberalerna 2001; Kristdemokraterna 2002; Miljöpartiet de gröna 2002; Moderata Samlingspartiet 2001; Sveriges socialdemokratiska arbetareparti 2002; Vänsterpartiet 2000). However, our interviews indicated that representatives from all political parties eventually supported the idea proposed by the governmental task force.

The final report of the expert task force was presented in October 2001, after which the government developed a law proposal and issued it for notification to the Commission. The scheme would expose renewables producers to market risks relating to fluctuating certificate prices, but they would be guaranteed a minimum 
price in the first five years of the scheme. Two weeks after receiving the notification, the Commission endorsed the Swedish proposal (Commission 2003). The guaranteed price was regarded as state aid, but in compliance with the exemptions allowed under the EU Treaty.

By now, the CJEU had sided with the German state in the PreussenElektra case, and the EU had adopted a Renewables Directive that did not require member states to develop certificate schemes (Boasson and Wettestad 2013: 86-87). These developments failed to de-legitimize the certificate idea in Sweden. Quite the converse: in April 2003, the Parliament decided to introduce a certificate scheme. The initial target was to produce $10 \mathrm{TWh}$ of renewable energy until 2010 (Swedish government 2003). The Social Democratic, Centre and Left Parties saw the phaseout of nuclear power as an important rationale here. In contrast, the Liberals and the Moderate Party voted against the bill, supporting nuclear energy and arguing that investments in renewable energy would be made also without support (Swedish Parliament 2003). Also, the Christian Democratic Party opposed the bill, preferring a feed-in scheme. The Green Party abstained from voting, arguing that it would be better to extend the $\mathrm{CO}_{2}$ tax.

Our interviewees agree that the electricity industry was not very involved in the decision-making process. The electricity market was almost as consolidated as it had been in the late 1990s, with three large electricity corporations accounting for more than $80 \%$ of annual electricity production in Sweden (Energy Market Inspectorate 2005). Vattenfall was the largest, supplying almost half of the electricity, and was also the third-largest actor in the German market, with a portfolio dominated by incumbent coal power production (Darmani et al. 2016). Vattenfall had indeed become a commercial player, making investment decisions based on short-term profit concerns, removed from long-term objectives set by the Swedish government. Several interviewees noted that, even though Vattenfall did not actively promote certificates, they were positive to this measure.

The scheme became an immediate success, in terms of expanding biopower. For the first years of operation, the certificate price was several times higher than the guarantied price (Ekonomifakta 2016). However, it took some time for the scheme to yield results in actual increased capacity other than biopower.

In this section, we have seen that EU influence played a major role in the establishment of the Swedish certificate scheme, and that the civil servants remained important. In the political field, Sweden's renewable energy policy languished in the shadow of the nuclear issue, and most electricity producers were rather uninterested.

\section{5-2010: booming renewables investments, and modest industry diversification}

In this period, the certificate scheme spurred a boom in biopower as well as windpower in Sweden. Investment support for solar power was introduced and proved far more popular than anticipated. The politically controversial issue was the lifting of the ban on nuclear power expansion. 
Sweden has long had a large share of district heating, fuelled primarily by biomass and waste. The certificate scheme made biomass electricity a profitable by-product of already-existing district heating and the pulp-and-paper industry (Engström 2015; Jacobsson 2008). Windpower development did not immediately take off to the same extent. Gradually, Vattenfall became more interested; by 2005 its declared aim was to be the largest windpower producer in Europe (Darmani 2016: 13, 14). Vattenfall also experienced costly nuclear incidents in Sweden and abroad, increasing its interest in other energy sources (ibid.: 13).

With the bioenergy boom, the dominance of Vattenfall was reduced to $44 \%$ by 2008, but Vattenfall, together with E.ON (earlier, Sydkraft) and Fortum, provided $79 \%$ of Sweden's electricity (Energy Market Inspectorate 2010: 24). No new renewables industry emerged, but the Swedish pulp-and-paper industry gained a more prominent role in the organizational field. The scheme has been criticized for favouring mature technologies, but it was generally popular within the industry as well as in the political establishment (Bergek and Jacobsson 2010; Jacobsson 2008: 1505; Söderholm and Pettersson 2011: 521). Another development in the organizational field was that the utilities previously dominated by engineers became heavily influenced by the market thinking of economists (see Inderberg 2012).

As part of a portfolio of measures introduced to enhance the energy performance of buildings, the first solar support scheme was introduced in 2005 (Näringsdepartementet 2008). Publicly owned buildings now became eligible for up-front support covering part of the cost of investments. This scheme was initiated in relation to Swedish implementation of the EU Energy Performance of Buildings Directive (Boverket 2009). The Directive promoted (in non-binding terms) installation of PV on buildings and encouraged member states to focus on public buildings. Our interviews indicate that the Parliament endorsed the scheme without political controversy. EU state-aid guidelines allowed for solar investment support, even though many countries, among them the UK and Germany, were opting to apply feed-in to promote solar (Leiren and Reimer 2021; Rayner et al. 2021, both in this book). The solar power support scheme was eventually designed to fit the requirements in the EU state-aid guidelines. Getting formal approval from the Commission took longer than expected, but it does not seem as if inputs from the Commission led to any significant changes in the scheme (Boverket 2009).

In 2006, the Social Democratic government proposed prolonging the certificate system until 2030, which meant expanding the target to 17 TWh by 2016 (Swedish Government 2006). As in 2003, the Centre, the Left and the Social Democrats favoured the scheme, while the Liberal Party and the Moderate Party wanted it revoked (Swedish Parliament 2006). The Christian Democratic Party repeated its call for a feed-in tariff. The Green Party had many objections to design details and called for support to a wider range of technologies and a higher renewables target. After a revised version of the scheme was passed by the Parliament, windpower investments increased (Pettersson and Söderholm 2009: 2036).

In September 2006, Swedish national elections resulted in a shift of government, and the Moderates, the Liberals, the Centre Party and the Christian Democratic 
Party formed the 'Alliance' coalition government. Describing energy as the most challenging issue for this government, one of our interviewees (15) stressed that the government managed to 'keep peace publicly', but the internal disagreements were significant. The Centre Party wanted to increase the targets in the certificate scheme; the others wanted to stall the nuclear phase-out.

In November 2008, the Swedish Ministry of Enterprise informed the Commission that it aimed to include private citizens and commercial actors in the solar investment support scheme (Näringsdepartementet 2008). The Ministry requested swift notification, arguing that, with the scheme for public buildings expiring soon, Sweden was about to enter a period without any functioning scheme. Correspondence records show that it took several months of informal deliberations before the Swedish government managed to adjust the design of the scheme to the EU state-aid requirements (Commission 2009). In May 2009, the Commission endorsed the scheme - but the notification was valid only until December 2011 and could not be prolonged without re-notification.

Interviewees indicate that the Centre Party used its leadership of the Ministry of Enterprise to promote the solar scheme, but there was also support from the opposition, solar power actors, and environmental protection groups. Although technologyneutrality was accepted as a guiding principle for the government's energy policies, all political parties, including the more nuclear-friendly Liberals and the Moderate Party, accepted the according of special treatment to solar energy. The Ministry of Finance, led by the Moderate Party, was sceptical - but our interviewees stress that solar was not expected to constitute a significant part of the energy mix, so the issue was regarded as of minor importance. The conflict was resolved at the highest political level, in internal negotiations among the coalition parties.

As so often before, the nuclear issue generated major political divisions in Sweden. In March 2009, the parties in government settled on a climate and energy agreement that opened up for replacing old nuclear reactors, which meant ending the ban on nuclear power expansion (Swedish Government 2009a, 2009b). At the same time, the government made decisions that reduced the profitability of nuclear: nuclear energy would not be eligible for subsidies, the safety requirements became stricter and the nuclear energy owners' liability responsibilities in case of accidents were increased (Swedish Government 2009c). Moreover, the certificate scheme was given an expanded production target for 2020 and was prolonged until 2035 - thus, the last actors to enter by 2020 will be entitled to certificates for 15 years.

Several interviewees $(1,6,15)$ held that the Centre Party called for higher ambitions in the certificate scheme in return for agreeing to lift the nuclear ban. Although ending the ban on nuclear energy was hard to swallow for the antinuclear Centre Party, it could also be reasoned that subsidizing renewable energy without giving nuclear energy new state aid made it impossible in practice to construct new reactors anyway: a question of 'letting nuclear energy dismantle itself' (Interview 9). However, some scholars claim that the 2009 agreement served to prolong the life of nuclear energy in Sweden, hampering the expansion of renewables (Sarasini 2009: 650; Tobin 2015: 148). 
The new Swedish agreement implemented the revised EU 2009 Renewables Directive. As with the first directive, actors favouring a pan-European certificate scheme failed to exert influence here. Interestingly, it does not seem as if the failure of certificates at the EU level served to de-legitimize the Swedish certificate scheme. The 2009 EU Directive entailed a binding renewable energy target of $49 \%$ by 2020 for Sweden, which the Swedish Parliament later raised to $50 \%$ (Swedish Government 2009a, 2009b). Moreover, the Swedish and Norwegian governments agreed that Norway should join the certificate scheme (Boasson $2021 \mathrm{c}$, this book). This spurred intense collaboration between the energy agencies of the two countries, but our interviewees agree that it did not lead to significant changes in design (see also Swedish Government 2010). The EU Directive also played an important role in the making of the 2009 Swedish agreement. The Alliance government had initially planned to postpone any major energy-policy decisions in order to keep peace internally. According to an interviewee (1) from the Alliance government, the need to implement the Renewables Directive was a key incentive for creating the 2009 agreement.

Thus, nuclear and renewable energy became more politically interconnected in this period, a development further reinforced after 2010 (see the next section). Influenced by the EU, Sweden introduced aid for micro-generation, but the rapid diffusion of feed-in schemes in the European environment did not affect Swedish support schemes.

\section{0-2016: certificate scheme prolonged against all odds}

After 2010, the big Swedish utilities as well as the EU generally turned against designing renewables support as certificate schemes. All the same, the Swedish scheme was prolonged and made more ambitious. To understand this, we need to examine the extraordinary political situation in the Swedish Parliament and the increased politicization of renewables.

We observe a remarkable shift in the larger European environment in this period. The 2008 financial crisis and the steep reduction in the cost of renewable energy led to criticism of feed-in schemes, especially from the financially constrained electricity utilities (Boasson 2021b). Moreover, the EU's steering of renewables support schemes became significantly more coercive in 2014, when the Commission issued guidelines that clearly favoured auctioning combined with feed-in premium. This created a shift from traditional feed-in schemes to auctioning plus feed-in premium all over the EU, also in feed-in champion Germany (Boasson 2021b; Leiren and Reimer 2021, both in this book). Energy policy developments in Sweden were, however, of quite a different nature, and very few actors tried to bring 'European' developments to Sweden.

In May 2010, the Swedish Parliament endorsed implementation of the Alliance government's 2009 energy agreement. The minority opposition favoured expansion of the certificate scheme with 5 TWh more, called for additional technologyspecific feed-in tariffs and accused the government of being too nuclear-friendly (Bolund et al. 2010). Both the government and the opposition appeared as two 
coherent blocs, and none of the parties that had previously opposed the certificate scheme voiced open criticism.

In the 2010 elections, the Alliance lost its parliamentary majority, and the rightwing populist party, the Sweden Democrats (Sverigedemokraterna), entered the Parliament; however, the Alliance still had more seats in Parliament than the redgreen parties (the Social Democratic, the Left, and the Green Parties). As the redgreens refused to cooperate with the Sweden Democrats, the Alliance continued as a minority government. The deep-seated conflicts over energy policy became fiercer, forcing the government to forge alliances with other parties in order to achieve parliamentary support (Interview 15).

The 2020 target of 50\% renewables energy consumption was reached already in 2012 (Energy Agency 2014: 39). In that year, windpower became the dominant technology in the certificate system, as older biopower facilities were phased out and windpower investments were growing almost exponentially (Energy Market Inspectorate 2010, 2014: 24). Vattenfall, Fortum and E.ON dominated electricity production, with more than $83 \%$ of the market, but a range of new electricity providers had emerged as well (Bergek et al. 2013; Energy Market Inspectorate 2014: 26). These new windpower investors had highly varying backgrounds (Darmani 2015), but corporations that sold biopower based primary on waste management, pulp-and-paper and agriculture dominated. By now, Vattenfall's European ventures had become very, very expensive: turning from Europe, the Swedish home market became more important (Darmani et al. 2016: 15).

The 2014 Swedish elections brought a minority government consisting of the Social Democrats and the Green Party. As this government lacked a stable basis in the Parliament, Swedish politics became significantly messier, with alliances shifting across issues. In 2015, the new government gained parliamentary support to up the target for Sweden in the Swedish-Norwegian scheme to finance $30 \mathrm{TWh}$ new renewables to 2020, replacing the earlier target of 25 TWh (Swedish Government 2015a).

In addition to the existing solar investment scheme and certificates, the new government introduced tax reduction for small-scale renewable electricity. Interviewees indicate that the solar industry association had initially pushed for a system that would reward who fed that electricity into the net, but the government argued that this would not be compatible with EU state-aid and competition policy (SOU 2013). The renewable electricity industry, the red-green parties, and the Energy Agency disagreed, while the Sweden Democrats opposed any such aid (Jakobsson 2014; Nordin 2013; Motion 2014). All the same, the Swedish government had to negotiate with DG Competition for more than a year before agreement was reached on how to design the tax exemption (Swedish Government 2014: 9).

In March 2015, the Swedish government appointed a parliamentary task force, instructed to propose a broad energy policy agreement by January 2017 at the latest (SOU 2017: 29). The group was headed by the Minister of Energy; the directors of the Transmission System Operator, the Energy Agency and the Energy Market Inspectorate participated in all meetings. Corporate actors were 
consulted but were not formally included in the task force. In January 2016, Vattenfall, surprisingly, announced that all its Swedish nuclear power plants would have to close down because of the low electricity prices, the effect of the tax on nuclear power and the new safety requirements (Dagens Industri 2016). Not only would that mean enormous losses to the state-owned company, it would put the entire Swedish electricity system at risk (SOU 2017). Interviewees confirm that politicians from most parties deemed it critical to respond swiftly to Vattenfall's latest move. Hence, they set about negotiating a new energy agreement - one year before the task force had planned to finalize its technically and scientifically informed assessment.

The traditional electricity industry had now turned more negative towards the certificate scheme, claiming that new renewables production was the main cause of the 65\% drop in wholesale Swedish electricity prices between 2010 and 2015 (Hirt 2016). Several interviewees emphasized that Vattenfall aimed at influencing the politicians' decisions on nuclear, paying less attention to renewables. At the time of these negotiations, the Norwegian government had already decided to leave the certificate scheme after 2020, but this did not influence the Swedish decisions much (Boasson 2021c, this book). Moreover, in 2014 the Commission issued new state-aid guidelines, requiring auctioning combined with feed-in premium. Certificate schemes could also be acceptable if certain design criteria were met (Boasson 2021b, this book). Interestingly, the final report from the parliamentary task force makes only a superficial reference to EU state-aid guidelines - indicating that these received little attention from the politicians (SOU 2017: 67-68).

In June 2016, the parties in government (the Social Democrats and the Green Party) and three of the four parties of the former centre-right Alliance Government (now in opposition) struck an energy policy deal. The overall goal was for Swedish energy production to be $100 \%$ renewable by 2040 (SOU 2017: 16). However, ambiguity entered the picture: this was 'a goal, not an end date prohibiting nuclear power', and it did not imply 'a politically forced closure of nuclear'. This new agreement also removed the thermal effect tax on nuclear power production, while ensuring that nuclear would not be allowed state aid in any form (SOU 2017: 17). On the other hand, the certificate scheme was prolonged and expanded by $18 \mathrm{TWh}$ worth of certificates until 2030, setting an end-date of 2045 .

Interviews with politicians in the task force indicate that they were motivated to reach an agreement well in advance of the 2018 elections. A dominant view held by many actors in both the political and the organizational fields was that nuclear energy was central in delivering sufficient effect in the Swedish electricity system. In this view, reducing taxation was necessary to keep nuclear plants in business, thereby ensuring the safety of the power system and that 'the lights didn't go out' (Faber 2018). According to our interviewees, the Centre and Green Parties pushed hard for expansion of the certificate scheme, whereas the other parties accepted this on the condition of reduced taxation for nuclear energy and large hydropower.

In a press release, the Green Party stated that the agreement meant 'step by step leaving old nuclear power and fossil electricity behind us' (Miljöpartiet 2016). 
In contrast, the Moderate Party claimed that it had secured 'the conditions for nuclear power to be an important part of Sweden's energy supply for a long time to come' (Moderaterna 2016). The Christian Democratic Party even proclaimed that they had 'saved nuclear power' (Kristdemokraterna 2016). By contrast, the Liberals and the Swedish Democrats opposed the agreement, which they felt would mean overly hefty subsidiaries to renewables (SOU 2017: 333, 338). The Left Party (Vänsterpartiet) also opposed the agreement, mainly because it was too nuclear-friendly (SOU 2017: 352).

The prolongation of the certificate system ran counter to the inputs from the electricity industry to a public consultation over the future design of the scheme in 2015 (Energy Agency 2015). Vattenfall, E.ON, several medium-sized electricity utilities and the Swedish Energy Business Association (Svensk Energi, later changed name to Energiföretagen Sverige), criticized the system; it had been effective in the past, but it did not solve the current challenges. E.ON explicitly called for a system based on auctioning, similar to the system prescribed in the new EU state-aid guidelines (see Boasson 2021b). Fortum was the only major producer that did not voice criticism. The pulp-and-paper business association, the Swedish windpower organization and environmental NGOs supported continuation of the system. The bioenergy association criticized certificate schemes for not being market-based and for causing too-low prices.

The fate of Sweden's certificate scheme was related to the sudden nuclear controversy in 2016. The unstable parliamentary situation contributed to heighten the level of political conflict related to nuclear as well as renewables. Advocates of a prolonged certificate scheme were to a surprising degree unconcerned about the factors that undermined the legitimacy of this scheme. Also in this period, Swedish civil servants engaged in several lengthy negotiations with the EU on the detailed design of the two support measures for solar energy. Consensus was lacking on how to interpret the various EU rules, and the dialogue with the EU contributed to create instabilities in these support schemes (Interview 9).

\section{Discussions and conclusions}

Sweden's renewables support mix consists of a certificate scheme for large-scale renewables with direct investment support for solar power and tax reductions for small-scale renewable energy. All schemes expose renewables producers to the electricity price, and almost all renewables investors and/or producers are eligible for support. The certificate scheme is not directly technology-specific (it includes both large- and small-scale renewables), whereas small-scale support applies only to small-scale renewables - in practice, mainly solar power.

To what extent and how has the European environment influenced the Swedish renewables support mix? From the late 1990s and onwards, Sweden's support schemes have emerged in conjunction with developments at the EU level, but political constellations and conflicts in Sweden differ from those at the EU level. In Sweden, the large electricity utilities did not promote the certificate scheme, and feed-in was hardly mentioned as a serious alternative. 
Swedish civil servants transferred the green certificate idea from Brussels in the late 1990s, expecting that a pan-European certificate scheme would soon emerge. This led to the adoption of the certificate scheme. This did not happen, but instead feed-in schemes became much more common in Europe. These European developments had no significant effect on Sweden. The adoption of the 2009 EU Renewables Directive with mandatory national renewables target had some impacts on the ambitions of the certificate scheme, but not on the design of the scheme itself. The Commission's shift away from electricity certificates as the ideal model in 2014 had limited influence on Sweden's energy policy.

The promotion of rooftop PV on public buildings in the 2002 EU Directive on Energy Performance of Buildings seems to have spurred the development of a solar investment scheme for public buildings, although the directive did not require this. The scope of the scheme was gradually expanded as commercial as well as individual households were included. The initial design of this scheme was neatly adjusted to the requirements of the EU state-aid guidelines, but Sweden applied an investment scheme, not a feed-in scheme like most other EU countries. Moreover, the time-consuming Commission notification procedures created substantial instabilities in the system, which in itself fostered demands for additional support schemes. This contributed to explaining why Sweden in 2015 introduced a tax reduction on top of its other support measures for solar power.

In contrast to the expectations set out in Chapter 3 (Boasson 2021a, this book), we find that the European environment had the most significant influence on Swedish renewables developments in a period when the EU had the least formal powers. EU influence was crucial for the development of the Swedish certificate scheme, and the idea later became consolidated and more resilient. Because it had been influenced by the Commission at such an early stage, by 2014 Sweden had a scheme that did not violate the new state-aid guidelines. In general, we can note that Sweden has been far more affected by the ideas advanced by the Commission and the European electricity industry, compared to the policies of other EU member states. Indeed, Swedish politicians held on to this instrument after 2010, despite substantial opposition from the domestic organizational field. The original EU impulse froze. Sweden held on to the technology-neutral idea of electricity certificates, even though very few other actors followed suite.

To what extent, when, and how has the Swedish organizational field of stationary energy production influenced the support schemes? In the 1970s, the field was segmented and the institutional logic of technology development had become highly institutionalized. The strong politicization of nuclear power came as an external shock to the field, but it did not lead to reduced internal unity of the field. Rather, nuclear expansion in Sweden continued for a full decade after the 1980 referendum, creating an electricity surplus that served to reduce the need for renewables.

The Swedish organizational field is segmented, although there is some variation over time. In the 1990s, a modest de-segmentation process in the field began, as market thinking gained prominence and a liberalization reform was implemented in Sweden. Moreover, the rise of climate change on the political agenda weakened 
Vattenfall's control of the field somewhat. The Energy Agency was established - a powerful regulatory agency that to some extent could counter Vattenfall in authority and knowledge. Moreover, the pulp-and-paper sector emerged as important energy producers, with more to gain from the development of new renewables (especially biomass) than the conventional actors. Together with E.ON/Sydkraft and Fortum, Vattenfall continued to control most of the Swedish electricity market, but the shift in logic from technology development to market thinking created internal tensions. It was the public actors who promoted electricity certificates; commercial actors seemed rather uninterested initially. Further, from 2000 and onwards, the field became heavily dominated by market logic, among the electricity producers as well as the Energy Agency. This mind-set eventually became heavily institutionalized, as shown by the smooth implementation of the certificate scheme.

In the period 2010-2016, the big utilities began questioning the market logic, and there came an influx of new, smaller actors. The utilities had experienced major economic problems, caused partly by market reactions to increased intermittent new renewables capacity, in Sweden and elsewhere. The utilities have neither resisted nor promoted the solar support schemes developed by the Energy Agency, even though this scheme is embedded in a technology development logic alien to the big utilities. At this stage, Sweden's solar industry was small but growing, and there seems to be a constructive dialogue with the Energy Agency, and with the politicians. The influx of a diverse group of solar and wind energy actors in the field does indeed contribute to creating more internal conflicts and less unity, making the field more pluralistic. This is illustrated by the actors' diverging perspectives to the 2015 consultation on the certificate scheme. In this period, the utilities, and especially Vattenfall, invested significant efforts in rescuing their nuclear facilities, while paying less attention to the renewables support schemes.

Therefore, we conclude that the segmented nature of the organizational field contributed to hindering development of ambitious renewables support in Sweden in the period leading up to the late 1990s. Subsequently, the shift to market logics and the diversity of actors involved served to make the field somewhat less segmented over time, but the change is modest. The adoption of the certificate scheme in 2003 was not precipitated by a united field but was rather a result of civil servants working to implement the political ambitions for renewables. From 2010 and onwards, we detect internal conflicts between the various groups of commercial actors over how to design renewables support. Importantly, the Energy Agency has been open to inputs from a range of actors, not only the dominant utilities. However, the field has still been rather segmented, and thus the Swedish Parliament's decision in 2016 to prolong various renewables support schemes despite lack of support among the major electricity producers cannot be explained by de-segmentation of the field. Moreover, Vattenfall expended few resources on influencing renewables policies, focusing instead on nuclear; the renewables issue was sacrificed partly because another issue (nuclear taxation) appeared more important at that point. All the same, the utilities' lack of political influence emerges as striking and contrasts with what we expected to find. 
Finally, to what extent and how did the Swedish political field influence the support schemes? The nuclear referendum in 1980 reinforced nuclear energy as a subject of intense political competition. The ambitious referendum result paved the way for a tradition of broad energy-political agreements in the Parliament. The structural power of the Parliament was further strengthened after the 2010 elections, due not least to the unstable parliamentary basis of the new minority government.

From 1980 to 1999, renewable energy held significant symbolic value - but, as Sweden already had abundant electricity production, renewables policy had very little practical importance. In the early 2000s, a political majority decided to adopt a more potent renewables support scheme. Notably, however, the design of the scheme was not politicized but delegated to civil servants and experts. In the period 2000-2009, we also observe rather unstable and rapidly shifting political positions on certificate schemes, except for the firm support from the Centre Party.

However, political discussions on renewables support have been increasingly intertwined with nuclear energy. The politicization increased after 2005, but only after 2010 have renewables support schemes become a salient political issue in their own right. However, it is hardly possible to separate the two issues. With respect to both nuclear and renewables, politicians across the parliamentary parties have tried to act in consistency with their former positions, presenting diverging interpretations of the ambiguous energy deal in the hope of being seen as winners. Thus, we see the dynamics of the Swedish political field as the main driver of developments in the renewables schemes after 2010 - whereas the influence of European developments or the organizational field has been limited. This explains why Sweden has extended the certificate period and upped the level of ambition. In addition, the investment support scheme and the tax reduction for solar energy production have achieved broad political support, although promoted by small and rather marginal actors in the organizational field. With political interest in introducing such support, the design was primarily a result of bureaucratic support in the Energy Agency.

In all periods after 1999, Swedish actors have devoted considerable resources, and increasingly so, to ensure that the Swedish support mix is in line with EU state-aid guidelines. This has probably been frustrating for the actors involved, but the lengthy and protracted dialogues with the Commission have had minor importance for the actual design of the resultant schemes. If anything, this has sustained the impression of unreliable support, perhaps fuelling demands for additional solar energy support - the tax exemption.

Against this backdrop, we conclude that after 2005, political steering has been an important explanatory factor for the design of the renewables support mix, and the political field grew even more important after 2010. This is in line with our expectation: the political field has influenced the development of renewables in the Swedish context to a greater degree when power has shifted to the Parliament regarding key decisions and when renewables have been subject to political competition. Ironically, the politicians made sure to 'freeze' an earlier EU impulse, implemented in a period when the civil servants ruled and political steering had 
less importance. And, interestingly, we find that the importance of the European environment has not been determined by the strength of coercive signals from the EU (vertical Europeanization), or the diffusion of practices in the European environment (horizontal Europeanization), but has been conditioned by the position of the two domestic fields.

\section{Interviewees}

1 Former political appointee (Centre Party), Ministry of Enterprise and Energy, 6 April 2017, telephone interview

2 Electricity industry representative, Swedenergy and Vattenfall, 15 November 2016, Stockholm

3 Civil servant, member of Electricity Certificate Task Force 2000-2002), 18 November 2016, Stockholm

4 Civil servant, Ministry of Enterprise and Energy, 13 March 2009, Stockholm

5 Former civil servant, member of Energy Task Force 2016-2017, 10 January 2017, Stockholm

6 Civil servant, Swedish Energy Agency, 14 October 2016, Oslo (identical to Interviewee 7 in Chapter 8)

7 Representative of the Confederation of Swedish Enterprise, 16 December 2016, Stockholm

8 Representative of Svenska Kraftnät (the Swedish TSO), 18 January 2017, Stockholm

9 Former civil Servant of the Ministry of Industry, 18 January 2017, Stockholm

10 Former political appointee (Centre Party), Ministry of the Environment, 30 March 2017, telephone interview

11 Electricity industry representative, Vattenfall, 15 November 2016, Solna

12 MP, the Moderate Party (liberal-conservative), 16 November 2016, Stockholm

13 Former civil servant (director), Swedish Energy Agency, 14 November 2016, Stockholm

14 Electricity industry representative, Vattenfall, 15 November 2016, Solna

15 Former political appointee (Centre Party), Ministry of Enterprise, and Energy and renewable energy industry representative, 16 November 2016, Stockholm

16 Renewable energy representative, Solar Energy Association of Sweden, 17 January 2017, Stockholm

17 MP, Centre Party, 16 November 2016, Stockholm

18 Civil servant, Svenska Kraftnät (the Swedish TSO), 18 January 2017, Stockholm

\section{References}

Andersson, K. (2013) Förnybar energi: Sveriges okända gröna revolution. Stockholm: Kungl. Skogs-och Lantbruksakademien.

Åstrand, K. (2005) 'Examining influences of EU policy on instrument choice: The selection of a green certificate trading scheme in Sweden', Policy and Society 24(2): 100-128. 
Åstrand, K. \& L. Neij (2003) Styrmedel för vindkraftens utveckling $i$ Sverige. Lund: KFS AB. Åstrand, K. \& L. Neij (2006) 'An assessment of governmental wind power programmes in Sweden - using a systems approach', Energy Policy 34(3): 277-296.

Bergek, A. \& S. Jacobsson (2010) 'Are tradable green certificates a cost-efficient policy driving technical change or a rent-generating machine? Lessons from Sweden, 20032008', Energy Policy 38(3): 1255-1271.

Bergek, A., I. Mignon \& G. Sundberg (2013) 'Who invests in renewable electricity production? Empirical evidence and suggestions for further research', Energy Policy 56: 568-581.

Boasson, E.L. (2021a) 'A dynamic multi-field approach', pp. 32-57 in E.L. Boasson, M.D. Leiren \& J. Wettestad (eds), (this book) Comparing Renewables Policy: The Role of Political, Organizational and European Fields. London: Routledge.

Boasson, E.L. (2021b) 'Europeanization of renewables support', pp. 58-72 in E.L. Boasson, M.D. Leiren \& J. Wettestad (eds), (this book) Comparing Renewables Policy: The Role of Political, Organizational and European Fields. London: Routledge.

Boasson, E.L. (2021c) 'Norway: Certificate supporters turning opponents', pp. 193-216 in E.L. Boasson, M.D. Leiren \& J. Wettestad (eds), (this book) Comparing Renewables Policy: The Role of Political, Organizational and European Fields. London: Routledge.

Boasson, E.L. \& J. Wettestad (2013) EU Climate Policy: Industry, Policy Interaction and External Environment. Farnham: Ashgate.

Bolund, P. et al. (2010) Motion 2009/10:N12 med anledning av prop. 2009/10:133 Höjda mål och vidareutveckling av elcertifikatsystemet. Parliamentary motion.

Boverket (2009) Utformningen reducerade effekterna - Boverkets utvärdering av OFFrotstödet. Karlskrona: Boverket.

Carlman, I. (1990) Blåsningen - Svensk Vindkraft 1973 till 1990. PhD Thesis, Kulturgeografiska Institutionen, Uppsala Universitet.

Centerpartiet (2001) Där människor får växa: idéprogram för Centerpartiet: antaget i Västervik 19 juni 2001. Stockholm: Centerpartiet.

Commission (2003) Statligt stöd N789/2002 - Sverige. Elcertifikatsystemet. Brussels, 5 February, C 382 fin.

Commission (2009) Statligt stöd N66/2009 - Sverige. Ördning för statligt stöd til solceller. Brussels, 19 November, C 4415.

Dagens Industri (2016) 'Vattenfall: Läget är ohållbart', 7 January.

Darmani, A. (2015) 'Renewable energy investors in Sweden: A cross-subsector analysis of dynamic capabilities', Utilities Policy 37: 46-57.

Darmani, A., N. Arvidsson \& A. Hidalgo (2016) 'Do the strategic decisions of multinational companies differ in divergent market contexts? An exploratory study', Energy Research \& Social Science 11: 9-18.

Ekonomifakta (2016) 'Elcertifikat', Updated 13 October 2016. Retrieved from www. ekonomifakta.se/Fakta/Energi/Styrmedel/Elcertifikat/, 16 August 2017.

Energy Agency (2003) Energiläget $i$ siffror 2003. Eskilstuna: Energy Agency.

Energy Agency (2014) 'Underlag till kontrollstation 2015. ER 2014:17', Retrieved from www.naturvardsverket.se/upload/miljoarbete-i-samhallet/miljoarbete-i-sverige/ regeringsuppdrag/2014/kontrollstation-2015-huvudrapport.pdf, 17 April 2017.

Energy Agency (2015) 'Kontrollstation 2015', Retrieved from www.energimyndigheten. se/fornybart/elcertifikatsystemet/kontrollstationer/kontrollstation-2015/, 17 April 2017.

Energy Agency (2016) 'Et norsk-svensk sertifikatmarked', Retrieved from www.ener gimyndigheten.se/globalassets/fornybart/elcertifikat/marknadsseminarium-2017/enmy4597-elcertifikat-2016-no_web.pdf, 17 April 2017. 
Energy Market Inspectorate (2005) Swedish Energy Markets Inspectorate's Annual Report to the European Commission in Accordance with the Proposed Reporting Structure. Stockholm: Energy Market Inspectorate.

Energy Market Inspectorate (2010) The Swedish Electricity and Natural Gas Markets 2009. EI R2010:12. Stockholm: Energy Market Inspectorate.

Energy Market Inspectorate (2014) The Swedish Electricity and Natural Gas Markets 2013. EI R2014:18. Stockholm: Energy Market Inspectorate.

Engström, S. (2015) Historien om den svenska vindkraften. Lidingö: Ägir Konsult.

Faber, H. (2018) Så länge man vill ha ljus hela tiden: En studie av hur avskaffandet av effektskatten på kärnkraft legitimerades. Master's Thesis. Stockholm University. Retrieved from http://su.diva-portal.org/smash/get/diva2:1191857/FULLTEXT01.pdf, 10 October 2017.

Folkpartiet Liberalerna (2001) Liberalismen. Stockholm: Folkpartiet Liberalerna.

Hirt, L. (2016) Reasons for the Drop of Swedish Electricity Prices. Project commissioned by the Swedish Business Association for Energy (Svensk Energi). Stockholm: Svensk Energi.

Högelius, P. \& A. Kaijser (2010) 'The politics of electricity deregulation in Sweden: The art of acting on multiple arenas', Energy Policy 38: 2245-2254.

Inderberg, T.H. (2012) 'Governance for climate-change adaptive capacity in the Swedish electricity sector', Public Management Review 12(7): 967-985.

Jacobsson, S. (2008) 'The emergence and troubled growth of a "biopower" innovation system in Sweden', Energy Policy 36: 1491-1508.

Jakobsson, L. et al. (2014) Motion 2013/14:Sk11 med anledning av prop. 2013/14:151 Skattereduktion för mikroproduktion av förnybar el. Stockholm: Riksdagen.

Kaijser, A. (1992) 'Redirecting power: Swedish nuclear power politics in historical perspective', Annual Review of Energy and the Environment 17: 437-462.

Kristdemokraterna (2002) Principprogram. Stockholm: Kristdemokraterna.

Kristdemokraterna (2016) 'Vi raddade karnkraften ock 400000 jobb', Retrieved from www.kristdemokraterna.se/Media/Nyhetsarkiv/Vi-raddade-karnkraften - och-400-000jobb/, 26 September 2016.

Leiren, M.D. \& I. Reimer (2021) 'Germany: From feed-in tariffs to greater competition', pp. 75-102 in E.L. Boasson, M.D. Leiren \& J. Wettestad (eds) (this book), Comparing Renewables Policy: The Role of Political, Organizational and European Fields. London: Routledge.

Miljöpartiet (2002) Partiprogram Miljöpartiet de gröna. Stockholm: Miljöpartiet de gröna.

Miljöpartiet (2016) 'Historiskt: Sverige ska få hundra procent förnybar el', Retrieved from www.mp.se/just-nu/historisk-overenskommelse-100-procent-fornybar-el, 26 September 2016.

Moderata Samlingspartiet (2001) Idéprogram. Stockholm: Moderata Samlingspartiet.

Moderaterna (2016) 'Vi har säkrat forutsetningarna för svensk kärnkraft', Retrieved from www.moderat.se/nyhetsartikel/vi-har-sakrat-forutsattningarna-svensk-karnkraft, 26 September 2016.

Motion (2014) Motion 2013/14:Sk10 med anledning av prop. 2013/14:151 Skattereduktion för mikroproduktion av förnybar el. Av Kent Persson m.fl. (V) Stockholm: Riksdagen.

Näringsdepartementet (2008) Statligt söd til solceller. Letter to the European Commission, 21 November. Stockholm: Regjeringskansliet.

Nilsson, M. (2005) 'Learning, frames and environmental policy integration: The case of Swedish energy policy', Environment and Planning C: Government and Policy 23: 207-226. 
Nohrstedt, D. (2005) 'External shocks and policy change: Three Mile Island and Swedish nuclear energy policy', Journal of European Public Policy 12(6): 1041-1059.

Nordhaus, D.W. (1997) Swedish Nuclear Dilemma: Energy and the Environment. Washington, DC: Resources for the Future.

Nordin, L. (2013) Skriftlig fråga 2013/14:278 Införandet av nettodebitering i Sverige. Stockholm: Riksdagen.

Pettersson, F. \& P. Söderholm (2009) 'The diffusion of renewable electricity in the presence of climate policy and technology learning: The case of Sweden', Renewable and Sustainable Energy Reviews 13: 2031-2040.

Rayner, T., M.D. Leiren \& T.H.J. Inderberg (2021) 'The United Kingdom: From marketled policy towards technology steering', pp. 103-125 in E.L. Boasson, M.D. Leiren \& J. Wettestad (eds) (this book), Comparing Renewables Policy: The Role of Political, Organizational and European Fields. London: Routledge.

Sarasini, S. (2009) 'Constituting leadership via policy: Sweden as a pioneer of climate change mitigation', Mitigation and Adaptation Strategies for Global Change 14(7): 635-653.

Söderholm, P., K. Ek \& M. Pettersson (2007) 'Wind power development in Sweden: Global policies and local obstacles', Renewable and Sustainable Energy Reviews 11(3): 365-400.

Söderholm, P. \& M. Pettersson (2011) 'Offshore wind power policy and planning in Sweden', Energy Policy 39(2): 518-525.

SOU (2001) Handel med elcertifikat: ett nytt sätt att främja el från förnybara energikällor: slutbetänkande. SOU 2001:77. Stockholm: Fritzes offentliga publikationer.

SOU (2013) Betänkande av utredningen om nettodebitering av el. SOU 2013:46. Stockholm: Fritze.

SOU (2017) Kraftsamling för framtidens energi: betänkande. SOU 2017:2. Stockholm: Wolters Kluwer.

Sveriges socialdemokratiska arbetareparti (2002) Partiprogram för Socialdemokraterna: antaget vid partikongressen 2001. Stockholm: Sveriges Socialdemokratiska Arbetareparti.

Swedish Government (1997) Regeringens proposition 1996/97:84 En uthållig energiförsörjning. Stockholm: Swedish Government.

Swedish Government (2000) Elproduktion från förnybara energikällor - ekonomiska förutsättningar och marknadsmekanismer. Departementsserien, Ds 2000:20. Stockholm: Swedish Government.

Swedish Government (2003) Regeringens proposition 2002/03:40 Elcertifikat för att främja förnybara energikällor. Stockholm: Swedish Government.

Swedish Government (2006) Regeringens proposition 2005/06:154 Förnybar el med gröna certifikat. Stockholm: Swedish Government.

Swedish Government (2009a) Förordning 2009:689 om statligt stöd till solceller. Stockholm.

Swedish Government (2009b) Regeringens proposition 2008/09:162 en sammanhållen klimat- och energipolitik - Klimat. Stockholm: Swedish Government.

Swedish Government (2009c) Regeringens proposition 2008/09:163 en sammanhållen klimat- och energipolitik- Energi. Stockholm: Swedish Government.

Swedish Government (2010) Regeringens proposition 2009/10:133 Höjt mål och vidareutveckling av elcertifikatsystemet. Stockholm: Swedish Government.

Swedish Government (2014) Lagrådsremiss: Komplettering av förslaget om skattereduktion för mikroproduktion av förnybar el. Stockholm: Swedish Government. 


\section{Elin Lerum Boasson et al.}

Swedish Government (2015a) Proposition 2014/15:123 Ambitionshöjning för förnybar el och kontrollstation för elcertifikatssystemet 2015. Stockholm: Swedish Government.

Swedish Parliament (2003) Riksdagens protokoll 2002/03:83 Wednesday 2 April. Stockholm: Riksdagen.

Swedish Parliament (2006) Riksdagens protokoll 2005/06:140 Tuesday 13 June. Stockholm: Riksdagen.

Tobin, P. (2015) 'Blue and yellow makes green? Ecological modernisation in Swedish climate policy’, pp. 141-155 in K. Bäckstrand \& A. Kronsell (eds), Rethinking the Green State. Routledge Studies in Sustainability. Abingdon, Oxford: Routledge.

Vänsterpartiet (2000) För en solidarisk värld: partiprogram antaget av Vänsterpartiets 33:e kongress 31/5-3/6 2000. Stockholm: Vänsterpartiet.

Vedung, E. \& M. Brandel (2001) Vattenkraften, staten och de politiska partierna. Falun: Bokförlaget Nya Doxa.

Wang, Y. (2006) 'Renewable energy in Sweden: An analysis of policy and regulations', Energy Policy 34(10): 1209-1220. 